\title{
The experience of contemporary peacekeepers healing from trauma
}

\author{
Susan L Ray \\ University of Western Ontario, London, Ontario, Canada \\ Accepted for publication 4 September 2008
}

SUSAN L. Nursing Inquiry 2009; 16: 53-63

The experience of contemporary peacekeepers healing from trauma

This research study was an interpretive inquiry into the experience of contemporary peacekeepers healing from trauma. Ten contemporary peacekeepers were interviewed who have sought treatment from trauma resulting from deployments to Somalia, Rwanda, and the former Yugoslavia. A thematic analysis of the text was undertaken, in which themes emerged to document and understand the ways in which contemporary peacekeepers heal from trauma. Narratives from the transcribed interviews were reviewed with the participants and reflective journaling by the researcher provided further clarification of the data to understand the experience. The peacekeepers' descriptions of the situations of their bodies in time, space and relation provided a fresh way into understanding the embodied nature of healing from trauma. Three overarching themes: the centrality of brotherhood and grieving loss in the military family; the centrality of time and the body in healing from trauma; and the military response as betrayal and creating trauma from within emerged from the inquiry which will contribute to more effective practice guidelines for the care of contemporary peacekeepers healing from trauma.

Key words: contemporary peacekeepers, healing, nursing, trauma.

All contemporary peacekeepers are soldiers trained to fight wars and to serve on peacekeeping missions. Peacekeeping missions require that they only intervene in self-defense (Rieff 1994). Therefore, contemporary peacekeepers felt helpless and powerless as they could not intervene in situations such as genocide, ethnic cleansing, etc. that took place on deployments to Somalia, Rwanda and the former Yugoslavia (Renner and Ayres 1993; Off 2001). Consequently, nurses are providing care to contemporary peacekeepers suffering from psychological trauma from these post-coldwar intrastate conflicts. It is vital that nurses understand the experience of contemporary peacekeepers healing from psychological trauma for the provision of knowledgeable and sensitive care.

This research study was an interpretive phenomenological inquiry into the experience of contemporary peacekeepers

Correspondence: Susan L. Ray, Faculty of Health Sciences, HSA \#32, The University of Western Ontario, London, Ontario, Canada N6A 5C1.

E-mail: slray@uwo.ca healing from trauma. However, many years after their deployments and treatment, the peacekeepers were still trying to heal from trauma and thus, their struggle with healing became a focus throughout the inquiry into healing from trauma.

\section{REVIEW OF THE LITERATURE}

Orienting to the phenomenon required a review of the literature to address the studies on contemporary peacekeepers and the studies on healing from trauma. Healing is the term which frequently appears in the literature on trauma and whose synonyms include recovery, improvement, transformation and revival.

\section{Studies on contemporary peacekeepers}

Despite widespread media coverage, much of the literature on contemporary peacekeepers is limited to anecdotal and individual descriptive accounts (Dallaire 2003), Questionnaire 
type surveys and structured interviews have provided qualitative descriptive thematic data about the positive and negative impact of peacekeeping deployments. Resilience to stress, a greater appreciation for freedom, an appreciation of 'things back home' and helping others during peacekeeping deployments had a positive impact on peacekeepers following exposure to traumatic events (Britt, Adler and Bartone 2001: Litz 2005; Britt and Dickinson 2006; Wessely et al. 2006; Maguen et al. 2008).

A number of studies reported that witnessing genocide, ethnic cleansing, torture, rape and mutilation of the innocent (such as women, children and the elderly) had the most negative impact (Lamerson and Kelloway 1996; Rosebush 1998; Passey and Crockett 1999; Roberts 2000; Maguen et al. 2004; Maguen and Litz 2006). Due to the rules of engagement (ROE), peacekeepers were required to monitor these atrocities passively, creating a sense of impotence, helplessness, lack of control and anger about their inability to meet the needs of the local population to relieve their suffering (Bartone, Adler and Vaitkus 1998; English 1999; Passey and Crockett 1999; Michel, Lundin and Larsson 2003). For many, the stress of peacekeeping came from professional difficulties and frustrations with the occupational role of being a peacekeeper, rather than from dangerous situations (Wessely et al. 2006). Needless to say, many experiences of dangers and threats to life were described by peacekeepers in several of the studies (Lamerson and Kelloway 1996; Rosebush 1998; Passey and Crockett 1999; Maguen and Litz 2006). The impact of trauma on peacekeepers can be associated with suffering from serious psychopathology such as post-traumatic stress disorder (PTSD), depression, suicide, alcohol abuse or dependence, generalized anxiety disorder, adjustment disorders and poor overall physical health (Bolton et al. 2003; Gray, Bolton and Litz 2004; Thoresen and Mehlum 2004; Wright et al. 2005; Adler, Castro and Britt 2006).

\section{Studies on healing from trauma}

Quantitative research studies have focused on healing or recovery from military trauma by measuring the efficacy of different therapeutic interventions for the reduction of PTSD symptoms, depression, anxiety and other diagnostic categories (Creamer et al. 1999; Foa et al. 1999; Keane and Barlow 2002; Taylor et al. 2003; Bormann et al. 2005; Bormann et al. 2006).

Qualitative research studies provide an in-depth richly contextualized understanding of healing from trauma from the perspective of survivors. The majority of qualitative research studies address the experiences of women and violence, male survivors of sexual abuse, Holocaust survivors and the refugee population (Anderson 2001; Miller et al. 2002; Draucker 2003; Scotten 2003; Paul 2004; Grossman, Sorsoli and Kia-Keating 2006; Ayalon et al. 2007; Banyard and Williams 2007; Parker et al. 2007).

Qualitative research studies on healing from military trauma are limited to Vietnam war veterans, Soviet veterans and Israeli soldiers. Karner (1994) interviewed 12 male Vietnam veterans diagnosed with PTSD to understand what Vietnam meant to and for these men. Interpretative procedures based on grounded theory were employed to explore the social construction of meaning. The theme of healing from trauma included remembering and retelling the trauma, the remembered selves or the past of the mind which included victims and aggressors, futures selves and the past and the future of memory.

Magomed-Eminov and Madrudin (1997) conducted two studies with Soviet veterans of the war in Afghanistan. Thirteen and nine themes, respectively, of intrapsychic conflict of the meaning of life emerged from the studies. The results supported the assertion that it is the existential crisis and inability to come to grips with a meaningful theory of life that causes the prolonged recovery or healing experienced by war veterans.

A phenomenological exploration of the experience of living with military-related PTSD of two Israeli soldiers was undertaken by Kroch (2004). The soldiers' lived experience of the diagnosis included: the intrusive character of traumatic memories; traumatic memories re-experienced vividly in their 'presentness'; traumatic memory reminders; traumatic meaning derived from the individual's personal history; the body re-experiences the trauma; the world is perceived as a dangerous place and the lived space is shrinking: living in a constant state of vigilance and past trauma as something that no one can comprehend and no words can describe. The study enriches understanding of the struggle with living with military-related PTSD.

In summary, the studies about contemporary peacekeepers are limited to quantitative methods, structured clinical interviews and qualitative questionnaire type surveys that focus on positive and negative impact, perceived needs, symptom checklists, PTSD risk factors and the prevalence of psychiatric disorders such as depression and PTSD. The qualitative studies on healing from military trauma are limited to Vietnam veterans, Soviet veterans from the war in Afghanistan and Israeli veterans from the Middle East conflict. There have been no qualitative studies on healing from military trauma experienced by contemporary peacekeepers who have served on deployments to Somalia, Rwanda and the former Yugoslavia. 
Before exploring the central question, I needed to recognize and address the value-laden prejudice, personal biases, life experiences and assumptions which impact upon my view of the phenomenon under discussion (Thompson 1985). I have been working for 25 years in mental health nursing with civilian populations suffering from various forms of trauma and the last three years as a clinical nurse specialist in an outpatient clinic for enlisted and veterans who have been traumatized from their military experiences. In my experience, diagnostic labels and stage models of healing or recovery are representations that fail to grasp the totality of the being before us. I believe that nurses and other healthcare professionals need to understand not only symptomatic responses but the experience of contemporary peacekeepers healing from trauma. The significance of this interpretive phenomenological study rests with the opportunity to provide a richer and deeper understanding of the experience of contemporary peacekeeping that leads to trauma and the experience of healing from trauma.

\section{METHOD}

\section{Theoretical underpinnings}

A philosophical inquiry of a hermeneutic and phenomenological nature as articulated by Van Manen (1998a) was the methodological framework used to guide this study. Hermeneutic phenomenology is an approach that lies within the tradition of human sciences and, by employing the methods of phenomenology and hermeneutics, is both descriptive and interpretive in nature. Hermeneutic phenomenology 'is the study of the life world - the world as we immediately experience it prereflectively, rather than as we conceptualize, categorize, or reflect on it' (9). Through a process of hermeneutic phenomenological reflection and writing, one thoughtfully brings to speech a reflective understanding of some aspect of the life world in such a way that both cognitive and non-cognitive meanings are revealed (Van Manen 1998a; Van Manen 2006).

\section{Participants}

The study was approved by the appropriate university ethics committee. A letter outlining the study was distributed to the Operational Stress Injury Social Support (OSISS) Groups for enlisted and veterans of the Canadian Forces (CF) throughout Ontario. A purposive sample of contemporary peacekeepers, aged 37-46 participated. The participants had been deployed to Somalia, Rwanda or the former
Yugoslavia. These deployments were chosen because they represent intrastate conflict (civil wars) which have erupted since the collapse of the Berlin Wall. All the participants had received treatment a minimum of 2 years (average length 6 years) for psychological trauma. It was important to interview peacekeepers who had received treatment for 2 years and who were in recovery a minimum of 2 years in order to explore their experience of healing from trauma. The 10 participants included six soldiers (Luke, Simon, Peter, James, John and Tim), two chaplains (Thomas and Matt), one medical assistant (Paul) and one female nurse (Mary). Their names were changed to pseudonyms for the purpose of anonymity and written consents were obtained from the participants.

\section{Procedures}

Van Manen (1998a) offers six dynamic interactive approaches for interpretive phenomenological inquiry and analysis of the data: orienting oneself to the phenomenon of interest and explicating assumptions and pre-understandings; investigating experiences as lived through conversational interviews rather than as we conceptualize it; reflecting upon and conducting thematic analysis which characterize the phenomenon and interpreting through conversations; describing the phenomenon through the art of writing and re-writing (re-thinking, reflecting, recognizing) which aims at creating depthful writing; maintaining a strong and oriented relation to the fundamental question about the phenomenon; and balancing the research context by considering parts and wholes.

All the data were collected before analysis via one or two audio-taped conversations with the 10 contemporary peacekeepers who served in Somalia, Rwanda and the former Yugoslavia. Each conversation lasted from 60 to 90 minutes and was transcribed verbatim into 20-30 double-spaced pages. During the conversation, the researcher invited the participants to recollect with minimal interruption their experiences of peacekeeping, how it lead to trauma and the experience of healing from trauma. The research questions that were asked, repeated as needed, were: What was the experience of contemporary peacekeeping and how did it lead to trauma? What is the experience of healing from the trauma of peacekeeping? and Are contemporary ways of treatment helping you to heal? It was not difficult to keep to the main research question on healing from trauma; however, the peacekeepers emphasized that they were still struggling with trying to heal from the trauma of their peacekeeping missions. Future conversations with the participants were negotiated as necessary to discuss and reflert 
on the evolving analysis and the interpretive description and comments were solicited for rigor and verification of meaning (Van Manen 1998a). Initially, the researcher conducted a holistic reading and thematic analysis of all the textual data to determine the themes that reflected the experience of peacekeeping. Subsequently, through the processes of reflection, writing and rewriting, these themes were transformed into 'more phenomenologically sensitive paragraphs' (Van Manen 1998a, 95) using the life world existentials of lived body (corporeality), lived space (spatiality), lived human relation (relationality or communality) and lived time (temporality) as guides for reflection in the research process. Reflective journaling by the researcher reinforced rigor as I was made aware of my aforementioned assumptions and biases in order not to conceal the experience of healing from trauma described to me by the participants. A valid interpretive-descriptive text 'is something that others nod to, recognizing it as an experience that one has or could have had' (Van Manen 1998a, 27). I considered the validity of the interpretive-descriptive text achieved when, after I discussed the evolving text with the participants, they responded with such statements as 'Yes, that's it. Yes, you've captured it'.

\section{FINDINGS}

As my topic explored as yet uncharted experiential data concerning contemporary peacekeeping, I chose to stay with their words as much as possible in order to capture the richness and poignancy of their lived-through experiences. As Van Manen (2006) stated, 'On the one hand, phenomenology is description of the lived-through quality of lived experience, and on the other hand, description of the meaning of the expressions of lived experience' (718). The first one is the immediate description of experience as lived and the second is a mediated description as expressed through writing and other types of symbolic forms (Van Manen 2006) that moves towards showing clearly the meaning of a lived experience that is often hidden from view. Therefore, I follow each excerpt with a mediated description that builds towards a structured thematic analysis. Consequently, the study evolved into a descriptive/interpretive one guided by a phenomenology. A deeper interpretation of the themes will be explored in the future. Although all the experiences described by the participants were unique, there were three common overarching themes: (i) the centrality of brotherhood and grieving loss in the military family; (ii) the centrality of time and the body in healing from trauma; and (iii) the military response as betrayal and creating trauma from within.

\section{THE CENTRALITY OF BROTHERHOOD AND GRIEVING LOSS INTHE MILITARY FAMILY}

\author{
The band of brothers
}

\begin{abstract}
That band of brothers kind of aspect. We're very close. The whole squadron lived in a carpet factory. Inside the carpet factory were rows of tents that we lived in. It's a very close environment that you live, eat, sleep, \& breathe, army guy stuff, 24 hours a day.
\end{abstract}

Being in the world of peacekeeping, involves a bonding or connectedness to each other that many of the peacekeepers describe as a band of brothers. The deep bond that develops over time is described as the band of brothers by soldiers throughout history in many literary sources (Shay 1994). This type of bond is particular to soldiers who live closely together and face life and death situations on a daily basis. Luke relates this bond to the closely lived shared space that provides varying degrees of safety as well as the felt space of closeness to each other. He compares this to an incarcerated prisoner who is serving time in a close confined space. The commitment to this closely lived space of contemporary peacekeeping does not end until the soldiers time also has been served.

\section{Connectedness to veterans}

The mother sent me a lovely letter. I was in my little village \& I'm watching TV. I thought oh my God, that's what she looks like. I was with your son when he died. She could be my mother. I just thought ... this is so odd. I don't know why it struck me at that moment. I went down to the cenotaph \& did our thing ... it's all so connected. At that moment that I saw her, like it is all so connected, the old vets, the old war $\&$ the more recent ones, its all interwoven $\&$ all just as stupid.

As a priest, Matt is asked to perform a Remembrance Day service at the village cenotaph. Instead, Matt decides to stand with the older veterans from the past wars. The bond or connectedness of the band of brothers struggling with healing from trauma is one that transcends one generation, to another generation of soldiers and from war to peacekeeping deployments. Back at his home, Matt speaks to the mother on TV that he recognizes as one that he sent a letter to about the last rites he gave to her son. Matt describes that this bond connects to the suffering of a silver cross mother who represents all the mothers across the generations who have lost their children to war and peacekeeping missions.

\section{Loss of a military brother}

One of our fellows killed himself by placing a grenade down his flack vest ... they saw the back panel of his flack vest with his spine and rib cage in tact on the roof with them. I was 
asked to go give last rites and then to do grieving with the troops. The Canadian General in charge of our contingent said this guy gets no funeral like other soldiers because he lacked moral fiber. That General doesn't deserve the dignity of a salute ... or the respect of their peers. There's no integrity. The man had his own personal beliefs about why someone took their life ... and that's a Canadian. Now this is 1994,50 years after the end of World War II.

Matt describes the traumatizing experience of the suicide of one of his brother soldiers serving in the former Yugoslavia. The experience of peacekeeping that leads to trauma includes dealing with the loss of one of their band of brothers who commits suicide. Matt goes on to describe that the refusal of a general in the military family to honor the death of a brother soldier who committed suicide further traumatizes and intensifies his struggle with healing from trauma as well as his fellow band of brothers left behind.

\section{Connectedness to the other}

\begin{abstract}
What traumatizes me; it's not blood and guts \& bullets... An old Somali guy asking for water ... about $6.5 \bullet$ tall \& easily 230 Ib. We were under strict orders ... \& I had to tell him no ... I told him sorry, and he understood that. It really made me feel so mad ... because I was there to help these people \& I actually had to stand there \& watch this old man... about late 50 s, early $605 \ldots$ He kept reminding me of my grandfather. I watched him walk away \& I kept turning around because I was wondering; where was he going with this big bucket of beans? Did he have a family? Was he looking after the grandchildren? I kept looking back to see where was he going.
\end{abstract}

Tim describes an incident in Somalia that traumatizes him. It is not blood, guts and bullets. One of the expectations of a soldier is the willingness to risk their lives and to expect blood, guts and bullets. What traumatizes Tim is his inability to help an older Somali man asking for some water. Although Tim connects the Somalia man with someone in his personal life (his grandfather), the rules of engagement require him to turn away from normal reactions in life. In life, one would normally assist someone asking for some water. The experience of peacekeeping that leads to trauma and the struggle with healing from trauma is one of connecting to another human that one has to turn away from responding to as a human being to the other.

\footnotetext{
The little girl was my daughter's age at the time. Her skuil had been cracked open like an egg by a machete. She was lying down on her side so the top of her head was cracked open. She had a smile on her face. This part was all opened up. Her face was nice \& pretty. A nice little girl. I remember looking at that \& saying, this is not a war!
}

Simon describes an incident that took place on a trail in Rwanda. The recognition of a dead man and a little girl murdered by the side of a trail brings home the reality that this is genocide, not war. The struggle with healing from the trauma of peacekeeping is connecting to an innocent, defenceless little girl laying exactly the way his daughter sleeps which is a reminder of the connectedness to his daughter back home. To this day, the connection of the little girl to his daughter makes Simon unable to go to his daughter's bedroom because of his fear of finding her dead.

\section{HEALING FROM TRAUMA: THE CENTRALITY OF TIME AND THE BODY}

\section{Time lost}

\begin{abstract}
There's two times I came across massacre spots. I don't remember seeing it ... I remember seeing everything that builds up to it. I remember seeing luggage blown up, blown up houses. I'm looking right at the person. The person beside me is describing a burnt body. I still can't remember it. So I went to Rwanda. There's four months gone by in neutral. I don't remember them ... I remember just working, leaving the camp from time to time.
\end{abstract}

Healing from the traumatic experiences of peacekeeping in the former Yugoslavia and in Rwanda involves the peacekeepers' struggle with the perception of the loss of time and thus, loss of memory. John remembers objects and conversations with other soldier peacekeepers leading up to the traumatic events but he does not remember actually witnessing these events. John describes this as 'mother nature' protecting him from this horror. Literature tells us that dissociation can be defined as an alteration in the unity of experience such that ' $I$ ', mind, body, world, or time is not integrated into the background (Beere 1995). There is a disruption or a disunity of time and thus, the traumatic events are not remembered. In John's words, it is 'mother nature' meaning his 'mind's way of protecting' him from experiencing the full emotional impact of the traumatic experience.

\section{Loss of feelings}

\begin{abstract}
I don't feel I have those feelings yet. I didn't feel anything at my grandfather's funeral. No sadness, no nothing. I just went there out of respect for my father. The only emotion I really have is anger \& the only other ... it's not really an emotion, but depression. I don't even know what happy is, or what sad is. So basically just anger \& depression.
\end{abstract}

Peter describes struggling with healing from the trauma of peacekeeping as experiencing difficulty with the perception of emotional detachment or numbing at home as a civilian. During the interview, Peter describes that civilian life requires the full range of emotions in order to connect and 
have relationships with his family and others. He perceives an inability to feel anything at his grandfather's funeral. He feels his emotions are limited to anger and depression. How is Peter able to relate to his friends and family with only anger and depression to convey his feelings? Peter feels that he is unable to recognize happy or sad. What is the long-term price of perceiving a detachment of feelings and emotions? According to Peter, it leads to a very lonely life back home. How do the peacekeepers remember all of their feelings and emotions necessary to live a civilian life?

\section{Loss of body}

I think that when I dissociate, my eyes become glazed, my body generally feels numb \& I don't feel 'real'.

Back home in Canada, Mary describes struggling with healing from trauma as experiencing the perception of disembodiment or dissociation. These alterations in perceptions have protected Mary, and other peacekeepers, from the emotional impact of the traumatic experiences overseas. However, once the peacekeepers return home, emotional and bodily loss or detachment prevents them from functioning effectively in the world or being at peace inside themselves (Stolorow, Atwood and Orange 2002). These alterations in perception of time, affect and the body can make these people painfully uncomfortable (Stolorow 2003). They are unable to either express or feel any emotion or are limited to anger and sadness. These same alterations in perception that enabled them to survive the trauma become obstacles in healing from the trauma once at home.

\section{The body remembers}

\begin{abstract}
On the video Crash Landing ... it brings back memories. The one guy was talking about the chicken; cooking chicken ... we had ordered chicken from a Lebanese pizza place. When I opened up the bag it was the same taste, the same smell as when I was over there. It smelled the same way; it was like ... I feel like I'm back there.
\end{abstract}

Paul describes struggling with healing from the trauma of peacekeeping as re-experiencing the trauma through the memories, feelings and emotions stored in his body. The body remembers and responds through the senses of smell, sight and sound. There is a visceral response so profound that the body automatically responds with flight from the traumatic memories, feeling and emotions. Does running from these bodily memories prevent healing from the trauma of peacekeeping deployments?

There are dates, like dates of events, flashbacks, smells. I was taught triggers \& what triggers stress \& the effects of stress.
There could be dates or anniversaries ... I look at my own life or lives of others \& think I might not have even been mentally aware or practically aware of what day it was when such \& such a thing happened, my body was, it knew exactly what day it was.

Matt describes struggling with healing from trauma as remembering painful memories stored in his body. The dates of events, flashbacks and smells are triggers or reminders of the trauma. He does not remember these triggers on an intellectual or mental level. Instead, his body reminds him of these traumatic memories and emotions. Matt reacts on a visceral level to triggers in his environment back in Canada. Matt goes on to explain that these bodily memories have prevented him from working as a parish priest. He is unable to control these traumatic bodily memories and emotions evoked by the world at home which force him to seek out a safe place. His familiar world from before the trauma is now unsafe as it triggers painful memories.

\section{THE MILITARY RESPONSE AS BETRAYAL AND CREATING TRAUMA FROMWITHIN}

\author{
Stigma from the military
}

\begin{abstract}
You still have to be very careful about coming forward. I was almost released from the military while I was trying to get myself better. It's not something that I broadcast around. The reality is that if you have an Operational Stress Injury (OSI), after two temporary categories they're supposed to put you on the permanent category called the SPHL (Service Personnel Holding List). Their experience is people do not get better and come back to work. Therefore, you end up medically released. The military says you're not going to be of any use to us with an OSI. I am still a valuable person with lots to offer. They say not with an OSI; not within the military.
\end{abstract}

Thomas describes struggling with healing from trauma as experiencing stigma from the military culture. Stigma from the military prevents Thomas and others from coming forward about his OSI. Although the military culture talks about all the progress made in regards to assisting those with an OSI, in reality they are automatically released from the Department of National Defense (DND) to the Department of Veterans Affairs (DVA). Thomas, a chaplain, was able to fight this process by taking some time off for spiritual care. He has fought being transitioned onto the SPHL and thus, released from the military to Veterans Affairs.

I was kicked out. Why not give those jobs to the people that want to stay in ... What it comes down to is respect. Don't disrespect him for doing his job. If he would have gotten his leg blown off you would have had a lot of respect for him. You can put your finger on the stump. 
James describes struggling with healing from trauma as experiencing stigma and the belief that a physical injury such as the loss of an arm or leg would be an honorable injury. He goes on to explain that the military would not ask any questions of a physical injury as this fits their perception of a veteran. Those with physical injuries are released with all the right things needed from their military family. A soldier with a psychological injury faces disrespect and the loss of his military family.

\section{The military family re-traumatizes}

I am as angry now at DND as 1 ever have been. Anger is destructive. There is nothing good that comes from anger. What does it do to the victim? It re-traumatizes. It just entrenches ways of acting, ways of thinking and ways of feeling that are not like giving at all. I can get over the Somali people, I suppose. I cannot forgive the DND. There has to be closure there. I cannot be angry the rest of my life. I'm a priest. I harbor more anger towards the DND.

Matt describes struggling with healing from trauma as experiencing re-traumatization from the military when the organization betray its commitment to the soldiers by releasing them once an OSI is diagnosed. Matt feels that he can heal from the trauma of peacekeeping deployments but that there will be no forgiveness towards the military until there is closure. Otherwise, he will remain angry the rest of his life at the DND.

To summarize, three overarching themes: (i) the centrality of brotherhood and grieving loss in the military family with the sub-themes of the band of brothers; connectedness to veterans; the loss of a military brother and the connectedness to the other; (ii) the centrality of time and the body in healing from trauma with the sub-themes of the loss of time; the loss of feelings; the loss of body; and the body remembering; (iii) the military response as betrayal and creating trauma from within with the sub-themes of stigma from the military and the military family re-traumatizes emerged from the inquiry. The three overarching themes and sub-themes are all simultaneously at play and not necessarily exclusive, and together capture the interpreted whole of the experience of contemporary peacekeeping healing from trauma. In phenomenology body in time, space and relation are intertwined and inseparable (Van Manen 1998a). By viewing the human subject as embodied and the body as a body-subject, healing from trauma is understood as a composite and complex whole that is experienced in the world in a concrete way.

\section{DISCUSSION}

The overarching theme of the centrality of brotherhood was captured in the excerpts, i.e. military family, brother and band of brothers as everyday talk of contemporary peacekeepers. The experience of soldiers calls forth the language and emotion of the earliest and strongest family relationships in every place and era (Shay 1994). Throughout history, brother and band of brothers are the most commonly spoken symbol of the bond between soldiers' closet comrades which is a closer bond than the one with their biological families as they face life and death situations together (Shay 1994).

Grieving loss in the military family was commonplace as many suicides occurred among peacekeepers who served on deployments to Somalia, Rwanda and the former Yugoslavia. Many peacekeepers expressed a sense of betrayal of 'what's right' or thémis (Shay 1994) by their leaders in regard to the treatment of their brothers who died. Many contemporary peacekeepers are denied compassionate understanding because it is difficult to comprehend a love between men that is rich and passionate but not necessarily sexual. For healing to take place, peacekeepers need to voice their grief and love not only for their dead military brothers but also for the loss of innocence, the loss of their band of brothers, their military family and their military careers.

The overarching theme of the centrality of time and the body in healing from trauma emerged from the peacekeepers descriptions of their experience of struggling with healing from trauma. The loss of the trustworthiness of perception in time and body is one of the major concerns for peacekeepers while healing from trauma. Effortless understanding of the perceptual background which establishes and reveals the contextual meaning for experience is an essential part of healing (Beere 1995). Throughout this study, peacekeepers described their struggle with healing as disruptions in their perception of time and their bodies. In phenomenology body in time, space and relation are intertwined and inseparable (Van Manen 1998a). Phenomenologically, we perceive the world with our bodies and thus are never able to be out of our bodies. The lived body is a bodily self that senses the qualities of the world in which it is immersed and situated. Nurses spend time bridging the monadic (gnostic body known to science) with the dyadic body (pathic body) that expresses itself (Van Manen 1999; Cameron 2006). Nurses try to understand the particularity of each suffering body and try to alleviate the suffering of the pathic body (Cameron 2006). The pathic body is where we live our lives and where the healing takes place.

Many peacekeepers have somatic complaints such as tension headaches, gastrointestinal disturbances, skin disorders, abdominal, back and neck pain as well as rapid heartbeat (Wagner et al. 2000; Norris et al. 2005).These somatic sensations are reminders of the traumatic memories stored in the body (Ogden and Minton 2000). Scaer (2001) 
asserts that when patients present with somatic complaints, it is important to question the patient about exposures to traumatic events. This is consistent with van der Kolk's (1994) thesis that the 'body keeps the score' when exposed to highly emotionally stressful events (254). The body's storage of traumatic memories and the impact traumatic memories have on the body are essential features of trauma and need to be addressed in the healing journey. Traumatic memories may be stored differently in the body (van der Kolk 1994). Whereas non-traumatic memories are stored in a verbal, linear narrative, traumatic memories are fragmented by the disruption in the unifying thread of time (Stolorow, Atwood and Orange 2002; Stolorow 2003). So long as the traumatic moments persist, the unifying thread of temporality is disrupted. While on deployment, the disruption in the unifying thread of temporality that links past, present and future shrinks the horizon to only getting through the now and to the timeless shelter of possible death (Shay 1994). Upon their return home, the disruption in the unifying thread of temporality accompanied by their inability to feel embodied emotions and feelings detaches many peacekeepers from their current life experiences. Rothschild (2000) asserts that, in order to heal, trauma survivors need to feel and identify their bodily sensations, learning to use language to name and describe them and articulate their meaning. According to Rothschild, the goals of therapy should be to reconcile implicit and explicit memories stored in the body into a comprehensive narrative of traumatic events and their aftermaths, to eliminate hyper arousal in connection with those memories, and to consolidate traumatic events into one's personal narrative.

\section{IMPLICATIONS FOR NURSING PRACTICE, EDUCATION AND FUTURE RESEARCH}

The unspeakable and unpresentable cannot be understood in current healing discourses or modalities. The centrality of the body in healing from trauma clearly shows that embodiment as articulated by Merleau-Ponty $(1962,1964)$ and Gadow (1999) is central to the experience of peacekeepers in their struggle to heal from trauma. However, embodiment is often overlooked or minimized in discussions of trauma. We must not forget the embodied nature of healing when caring for peacekeepers suffering from trauma (Ray 2006). Nurses need to return to the suffering of the pathic body, as described by the peacekeepers, to understand how trauma is lived. Embodied healing is done by peacekeepers, not to peacekeepers, as the presence of the body in life situations gives the other life existentials their meaning, i.e. time, space and relation (Ray 2006). Nurses need to be truly present with peacekeepers who are struggling to heal from their traumatic experiences. In order to be truly present, embodiment and embodied engagement need to be incorporated into the development of best practice guidelines for the nursing care of contemporary peacekeepers.

Nursing curriculums must include all forms of trauma including military related in order for nurses to be adequately prepared to assess and to begin to care for this population. Specialty programs are needed for advanced practice nurses (APN) to acquire the knowledge and expertise needed to provide the care for traumatized military personnel to heal from trauma. In nursing education, we must create our own understanding of healing which emphasizes communalization of the trauma. We need to educate nurses to promote a public attitude of caring about the conditions that create such psychological injuries and an attitude that will support measures to prevent as much injury as possible. Nurses, as healthcare leaders need to advocate for increased resources to be directed towards prevention, intervention and research.

Future studies both quantitative and qualitative are needed to address the efficacy of different treatment modalities in order to ensure that the best care is delivered to those who are struggling to heal from the trauma of peacekeeping deployments. Studies on best practices to address debriefing the immediate traumatic experiences in the field for the immediate care of the peacekeepers before returning them to Canada are needed. As well, wide-sweeping educational programs must be implemented for all personnel employed by the military and this will take studies in organizational cultural change and transformation. Although in this study the military family and the band of brothers that support those who are healing from trauma are highly significant, at the same time studies on how to prevent stigmatization by fellow military personnel are also urgently needed.

\section{RECOMMENDATIONS FORTHE MILITARY}

Although this study enriches our understanding of these particular peacekeepers' healing from the trauma of peacekeeping, it is also likely to be reflective of other military personnel who are experiencing trauma. Therefore, based on the findings from these 10 peacekeepers, the following are recommendations for the military organizational culture. The overarching theme of the military response as betrayal and creating trauma from within emerged from the conversations with the peacekeepers. All of the peacekeepers expressed a sense of betrayal by their home-front government, politicians and their military family. Upon their return home, the response of stigma by the military and subsequent release as 
the response to their suffering created further betrayal and trauma from within their military family. All the peacekeepers in this study felt that they were more affected by the negative reaction from their military family than from the trauma itself. They recommended that the military be aware of the additional traumatization inflicted upon their soldiers experiencing trauma who are released without any recognition. A parade and the awarding of the Wound Strip metal for psychological injury is one simple suggestion made by one of the peacekeepers for recognition and closure.

The peacekeepers recommended that the military leadership needs more compassionate training and expertise in regards to assisting those who have been traumatized from peacekeeping deployments to receive the care needed for healing to take place. The peacekeepers recommended that those who are healing from trauma stay in the military in order to make changes in the culture for themselves and their peers.

Operational Stress Injury Social Support (OSISS) groups have been established throughout Canada for enlisted and veterans. According to these peacekeepers, OSISS peer groups offer a connection to their band of brothers which allows them to grasp that they 'don't have to go through it alone' upon their return home. They recommended that more OSISS groups be established where peacekeepers' trauma stories can be shared safely in order to communalize their experiences.

\section{CONCLUSION}

The military needs to further their understanding about military psychological trauma and support those effected to obtain the proper treatment. Treatment approaches that focus on grieving the loss of the band of brothers and their military careers are needed for those personnel that are released after they have been diagnosed with PTSD and other mental health problems. Research studies are needed to test the efficacy of treatment approaches for PTSD especially those treatments that incorporate embodied healing such as complementary therapies. In light of the present deployments of multinational troops to Iraq, Afghanistan and elsewhere, there is urgency for future studies to respectfully address the findings in this study and to understand how to provide the best treatment approaches upon their return home.

\section{ACKNOWLEDGEMENTS}

This study was funded by an internal grant from the Social Science and Humanities Research Council (SSHRC).

\section{REFERENCES}

Adler AB, CA Castro and TW Britt. 2006. Military life: The psychology of serving in peace and combat. In Operational stress, eds AB Adler, CA Castro and T Britt, 141-69. Westport, CT: Praeger Security International.

Anderson KM. 2001. Recovery: Resistance and resilience in female incest survivors. Doctoral dissertation, University of Kansas.

Ayalon L, C Perry, PA Areán and MJ Horowitz. 2007. Making sense of the past: Perspectives on resilience among Holocaust survivors. Journal of Loss and Trauma 12: 281-93.

Banyard VL and LM Williams. 2007. Women's voices on recovery: A multi-method study of the complexity of recovery from child sexual abuse. Child Abuse and Neglect 31: 275-90.

Bartone PT, AB Adler and MA Vaitkus. 1998. Dimensions of psychological stress in peacekeeping. Military Medicine 163: 587-93.

Beere DB. 1995. Dissociative reactions and characteristics of the trauma: Preliminary tests of perceptual theory of dissociation. Dissociation 8: 175-2002.

Bolton EE, DM Glenn, SM Orsillo, L Roemer and BT Litz. 2003. The relationship between self-disclosure and symptoms of posttraumatic stress disorder in peacekeepers deployed to Somalia. Journal of Traumatic Stress 16: 20310.

Bormann JE, TL Smith, S Becker, M Gershwin, L Pada, AH Grudzinski and EA Nurmi. 2005. Efficacy of frequent mantram repetition on stress, quality of life, and spiritual well-being in veterans: A pilot study. Journal of Holistic Nursing 23: 395-414.

Bormann JE, D Oman, JK Kemppainen, SBecker, M Gershwin and A Kelly. 2006. Mantram repetition for stress management in veterans and employees: A critical incident study. Journal of Advanced Nursing 53: 502-12.

Britt TW and JM Dickinson. 2006. Morale during military operations: A positive psychology approach. In Military life: The psychology of serving in peace and combat: Military performance, eds TW Britt, CA Castro and AB Adler, 15784. Westport, CT: Praeger Security International.

Britt TW, AB Adler and PT Bartone. 2001. Deriving benefits from stressful events: The role of engagement in meaningful work and hardiness. Journal of Occupational Health Psychology 6: 53-63.

Cameron B. 2006. Towards understanding the unpresentable in nursing: Some nursing philosophical considerations. Nursing Philosophy 7: 23-35.

Creamer M, P Morris, D Biddle and P Elliot. 1999. Treatment outcome in Australian veterans with combat 
related post-traumatic stress disorder: A cause for cautious optimism? Journal of Traumatic Stress 12: 545-58.

Dallaire R. 2003. Shake hands with the devil: The failure of humanity in Rwanda. Random House.

Draucker CB. 2003. Unique outcomes of women and men who abused. Perspectives in Psychiatric Care 39: 7-16.

English A. 1999. Creating a system for dealing with operational stress in the Canadian forces: Board of inquiry - Croatia, 5-6. Ottawa: Government of Canada Publication.

Foa EB, CV Dancu, EA Hembree, LH Jaycox, EA Meadows and GP Street. 1999. The efficacy of exposure therapy, stress inoculation training and their combination in ameliorating PTSD for female victims of assault. Journal of Consulting and Clinical Psychology 67: 194-200.

Gadow S. 1999. Relational narrative: The postmodern turn in nursing ethics. Scholarly inquiry for Nursing Practice: An International Journal 13: 57-70.

Gray MJ, EE Bolton and BT Litz. 2004. A longitudinal analysis of PTSD symptom course: Delayed-onset PTSD in Somalia peacekeepers. Journal of Consulting and Clinical Psychology 72: 909-13.

Grossman FK, L Sorsoli and M Kia-Keating. 2006. A gale force wind: Meaning making by male survivors of childhood sexual abuse. American Journal of Orthopsychiatry 76: 434-43.

Karner TX. 1994. Masculinity, trauma, and identity: Life narratives of Vietnam veterans with post-traumatic stress disorder. Doctoral dissertation, University of Kansas.

Keane TM and $\mathrm{DH}$ Barlow. 2002. Posttraumatic stress disorder. In Anxiety and its Disorders, 2nd edn, ed DH Barlow, 418-53. New York: The Guilford Press.

van der Kolk BA. 1994. The body keeps the score: Memory and the evolving psychobiology of post-traumatic stress. Harvard Review of Psychiatry 1: 253-65.

Kroch R. 2004. The experience of living with military-related 'posttraumatic stress disorder' http://www.phenomenologyonline.com/articles/kroch.html (Accessed 28 October 2004).

Lamerson CD and E Kelloway. 1996. Towards a model of peacekeeping stress: Traumatic and contextual influences. Canadian Psychology 37: 195-204.

Litz BT. 2005. Has resilience to severe trauma been underestimated? American Psychologist 60: 262.

Magomed-Eminov E and S Madrudin. 1997. Post-traumatic stress disorders as a loss of the meaning of life. In States of mind: American and post-soviet perspectives on contemporary issues in psychology, eds D Halpern and AE Voiskounsky, 238-50. New York: Springer.

Maguen S and BT Litz. 2006. Predictors of morale in US peacekeepers. Journal of Applied Social Psychology 36: 82036.
Maguen S, BT Litz, JL Wang and M Cook. 2004. The stressors and demands of peacekeeping in Kosovo: Predictors of mental health response. Military Medicine 169: 198206.

Maguen S, DM Turcotte, AL Peterson, TL Dremsa, HN Garb, RJ McNally and BT Litz, 2008. Description of risk and resilience factors among military medical personnel before deployment to Iraq. Military Medicine 173: 1-9.

Merleau-Ponty M. 1962. Phenomenology of perception. trans. M. Smith. New York: Routledge.

Merleau-Ponty M. 1964. Eye and mind. In The primacy of perception and other essays. trans. C Dallery, 159-90. Evanston, IL: Northwestern University Press.

Michel PO, T Lundin and G Larsson. 2003. Stress reactions among Swedish Bosnia: A longitudinal study. Journal of Traumatic Stress 16: 589-93.

Miller KE, GJ Worthington, JD Muzurovic, S Tipping and A Goldman. 2002. Bosnian refugees and the stressors of exile: A narrative story. American Journal of Orthopsychiatry 72: 341-54.

Norris RL, S Maguen, BT Litz, AB Adler and TW Britt. 2005. Physical health symptoms in peacekeepers: Has the role of deployment stress been overrated? Stress, Trauma, and Crisis 8: 251-65.

Off C. 2001. The lion, the fox and the eagle: A story of generals and justice in Yugoslavia and Rwanda. Toronto: Vintage Canada.

Ogden P and K Minton. 2000. Sensor motor psychotherapy: One method for processing traumatic memory. Traumatology 6: 3-8.

Parker A, A Fourt, JI Langmuir, EJ Dalton and CC Classen. 2007. The experience of trauma recovery: A qualitative study of participants in the women recovering from abuse program (WRAP). Journal of Child Sexual Abuse 16: 55-77.

Passey G and D Crockett. 1999. Psychological consequences of Canadian UN peacekeeping. Ottawa: Government of Canada Publication.

Paul M. 2004. Clinical implications in the healing from domestic violence: A case study. American Psychologist 59: 809-16.

Ray SL. 2006. Embodiment and embodied engagement: Central concerns for the nursing care of contemporary peacekeepers suffering from psychological trauma. Perspectives in Psychiatric Care: The Journal for Advanced Practice Psychiatric Nurses 42: 106-13.

Renner $M$ and $E$ Ayres. 1993. Critical juncture: The future of peacekeeping. Washington, DC: World Watch Institute.

Rieff D. 1994. The illusions of peacekeeping. World Policy Journal 11: 3-18. 
Roberts P. 2000. War in peace: A field study in Bosnia of troops in a siege under fire. Presentation at the 16th annual meeting of the International Society for Traumatic Stress Studies. San Antonio, Texas.

Rosebush P. 1998. Psychological interventions with military personnel in Rwanda. Military Medicine 163: 55963.

Rothschild B. 2000. The body remembers: The psychophysiology of trauma and trauma treatment. New York: W. W. Norton.

Scaer R. 2001. The body bears the burden. Binghamton: Haworth Medical Press.

Scotten DD. 2003. Pre-verbal trauma, dissociation and the healing process. Doctoral dissertation, Leslie University, Cambridge, MA.

Shay J. 1994. Achilles in Vietnam: Combat trauma and the undoing of character. New York: Maxwell Mcmillan International.

Stolorow RD. 2003. Trauma and temporality. Psychoanalytic Psychology 20: 158-61.

Stolorow RD, GE Atwood and DM Orange. 2002. Worlds of experience: Interweaving philosophical and clinical dimensions in psychoanalysis. New York: Basic Books.

Taylor S, DS Thordarson, L Maxfield, IC Fedoroff and J Ogrodniczuk. 2003. Comparative efficacy, speed, and adverse effects of three PTSD treatments: Exposure therapy, EMDR, and relaxation training. Journal of Consulting and Clinical Psychology 71: 330-8.
Thompson JL. 1985. Practical discourse in nursing: Going beyond empiricism and historicism. Advances in Nursing Science 4: 59-71.

Thoresen S and L Mehlum. 2004. Risk factors for fatal accidents and suicides in peacekeepers: Is there an overlap? Military Medicine 169: 988-93.

Van Manen M. 1998a. Researching lived experience, 3rd edn. London, ON: The Althouse Press.

Van Manen M. 1999. The pathic nature of inquiry and nursing. In Nursing and the experience of illness, eds I Madjar and JA Walton, 17-35. Sydney: Allen \& Unwin.

Van Manen M. 2006. Writing qualitatively, or the demands of writing. Qualitative Health Research 16: 713-72.

Wagner AW, J Wolfe, A Rotnitsky, SP Proctor and DJ Erick. son. 2000. An investigation of the impact of posttraumatic stress disorder on physical health. Journal of Traumatic Stress 13: 41-55.

Wessely S, S Thomas, C Dandeker, N Greenberg and V Kelly. 2006. Serving in Bosnia made me appreciate living in Bristol: Stressful experiences, attitudes, and psychological needs of members of the United Kingdom armed forces. Military Medicine 171: 376-80.

Wright KM, PD Bliese, AB Adler, CW Hoge, CA Castro and $J \mathrm{~L}$ Thomas. 2005. Screening for psychological illness in military personnel. Journal of the American Medical Association 294: 42-3. 